\title{
Lévi-Strauss' photographs: an anthropology of the sensible body
}

Marcelo Fiorini

\section{OpenEdition}

Journals

Electronic version

URL: https://journals.openedition.org/jsa/10555

DOI: 10.4000/jsa. 10555

ISSN: 1957-7842

Publisher

Société des américanistes

\section{Printed version}

Date of publication: 20 December 2008

Number of pages: 55-67

ISSN: 0037-9174

\section{Electronic reference}

Marcelo Fiorini, "Lévi-Strauss' photographs: an anthropology of the sensible body", Journal de la Société des américanistes [Online], 94-2 | 2008, Online since 10 December 2013, connection on 02 September 2022. URL: http://journals.openedition.org/jsa/10555 ; DOI: https://doi.org/10.4000/jsa. 10555 


\title{
LÉVI-STRAUSS' PHOTOGRAPHS: AN ANTHROPOLOGY OF THE SENSIBLE BODY
}

\author{
Marcelo FIORINI *
}

Lévi-Strauss has been somewhat reticent about his own photographs, rarely writing about them, and sometimes presenting them merely as ethnographic documents to be used as supporting materials for cultural analysis. In this sense, it could at least be said that Lévi-Strauss' photographs should be considered an integral part of his ethnography. But I believe Lévi-Strauss' photographs are much more than this. They represent one of the first attempts in anthropology to show how the body makes sense. Moreover, since the photographs cover the period from 1936 to 1938, they are almost simultaneous to the work of Margaret Mead and Frances MacGregor (with photographs by Gregory Bateson, 1951) in Bali. More cautious than Mead, however, Lévi-Strauss never claimed that images could speak independently of one's ethnography and reveal an individual's psychological traits. His statements are regarding the structural characteristics of artistic expression and its relationship to dominant social structures that may linger even in the context of acculturation.
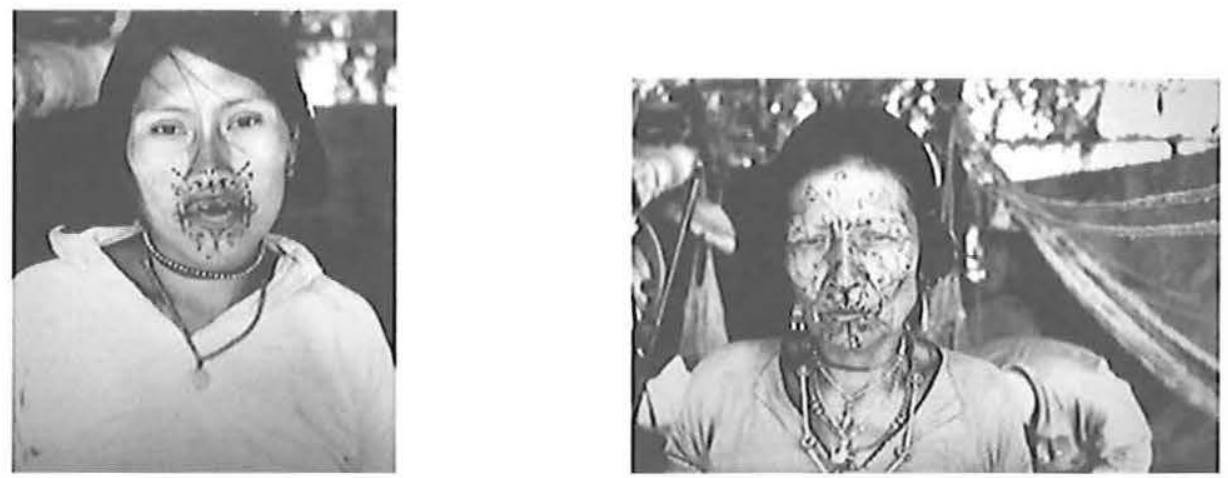

Caduveo facial drawings (Lévi-Strauss 1936)

*American university, 6 rue du Colonel Combe, 75007 Paris [fioriniorama@gmail.com]. Journal de la Société des Américanistes, 2008, 94-2, pp. 55-67. OSociété des Américanistes. 
Some of the bolder statements Lévi-Strauss did make in relation to photography - like his suggestion that about the Caduveo women's facial drawings he photographed express an ambivalence between hierarchical and egalitarian structures inherent to this society -, are based on his field observations of how nobles and commoners, warriors and vassals, men and women, are related in a society historically fraught by social differences. But Lévi-Strauss' own argument points to the relativity of this cultural feature, since the Caduveo sought dissimilar means of expressing themselves: the abstract women's drawings tellingly revealed this intrinsic tension of their lives, whereas the figurative sculptures and drawings were not directly related to such tensions. The efflorescence in Caduveo women's mouths, in this sense, is an expression of an unresolved contradiction, acting as a kind of deep structure inhabiting the lives and minds of certain individuals in Caduveo society. As Lévi-Strauss himself states: this contradiction continued to trouble the Caduveo in an insidious fashion, and because they paid no heed to it on a conscious level, they began to dream about it ${ }^{1}$.

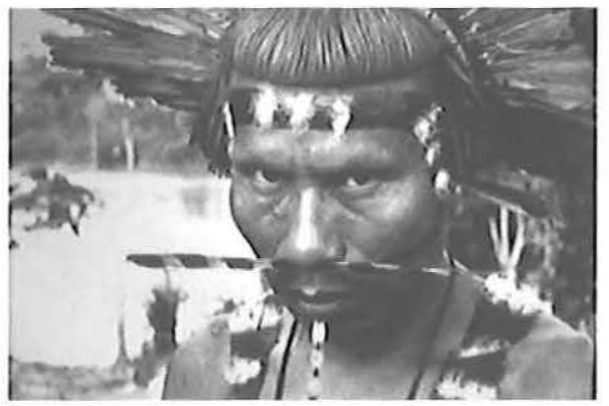

Lévi-Strauss' Bororo informant who met the Pope (Lévi-Strauss 1936)
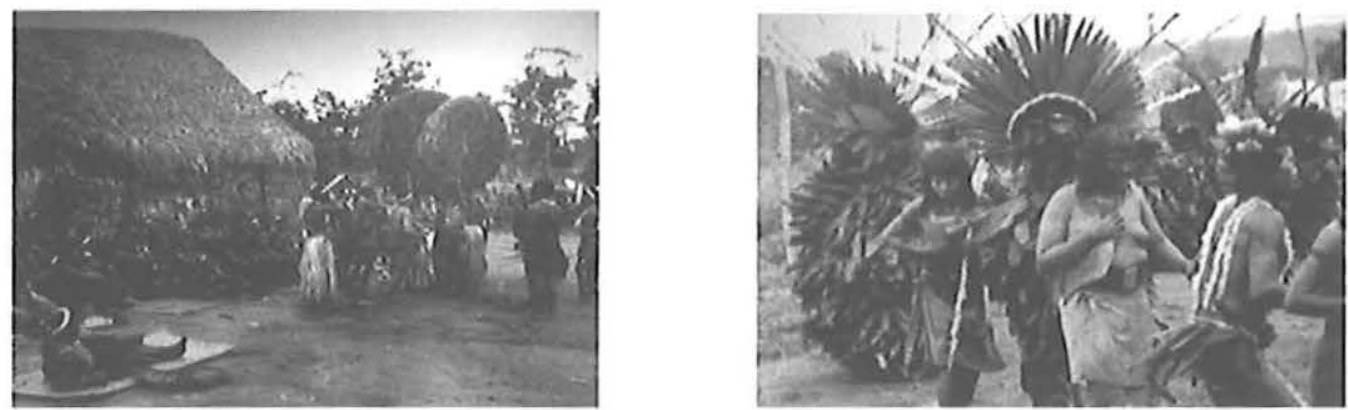

Scenes of a Bororo funeral (Lévi-Strauss 1936)

Perhaps we can say something similar about Lévi-Strauss' Bororo photographs, which give special attention to the funeral dances, to ritual performance 
and ornamentation that he claims are forms of transcending death and human destiny. Lévi-Strauss' films of the Bororo reveal his interest about the choreography of the funeral dance, from its preparation to its apotheosis ${ }^{2}$.
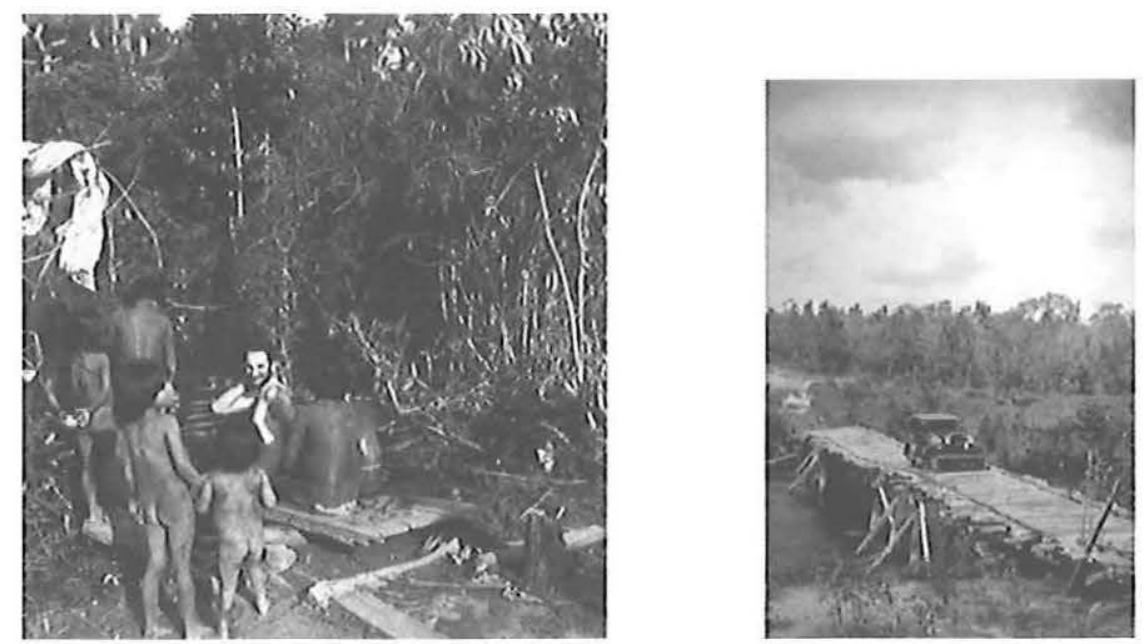

Claude Lévi-Strauss bathing and approaching the Nambikwara (Lévi-Strauss 1938)

But I will place my focus here on Lévi-Strauss' 1938 expedition, and his photographs of the Nambikwara, in order to show how they constitute, more comprehensively, one of the early ethnographic insights into the specific cultural lifestyle of this particular indigenous group. Let us first speak of Lévi-Strauss' influences. His father was a painter of portraits. Therefore, it is not surprising that Lévi-Strauss had acquired a great sensitivity for taking excellent portraits like the ones he took of the Nambikwara. But there is more to it than just this. One of the greatest influences on Lévi-Strauss at the time was Robert Lowie, whose Primitive Society (1920) already developed some of the notions of what later became known as ethos, the specific cultural styles of diverse societies. This concept of ethos originated from the Boasian tradition in anthropology that later became a source of inspiration in the work of Lévi-Strauss. Another great influence on Lévi-Strauss was his teacher Marcel Mauss, whose concept of body techniques Lévi-Strauss surely carried to the field (Mauss 1934). Lévi-Strauss' Nambikwara photographs can be seen as close to forming a compendium that illustrates how the Nambikwara sit, lie down, nurse and carry babies, foster younger siblings, groom each other, sleep and work; how women make necklaces 
or how men make curare in preparation for the hunt. They also illustrate how the Nambikwara move in groups through the savannahs, how they adorn or lounge and play among themselves, how the women sport monkeys on their heads as if they were hats, and how children also care for their own pets, carrying them as if they were their own offspring (the list could go on).
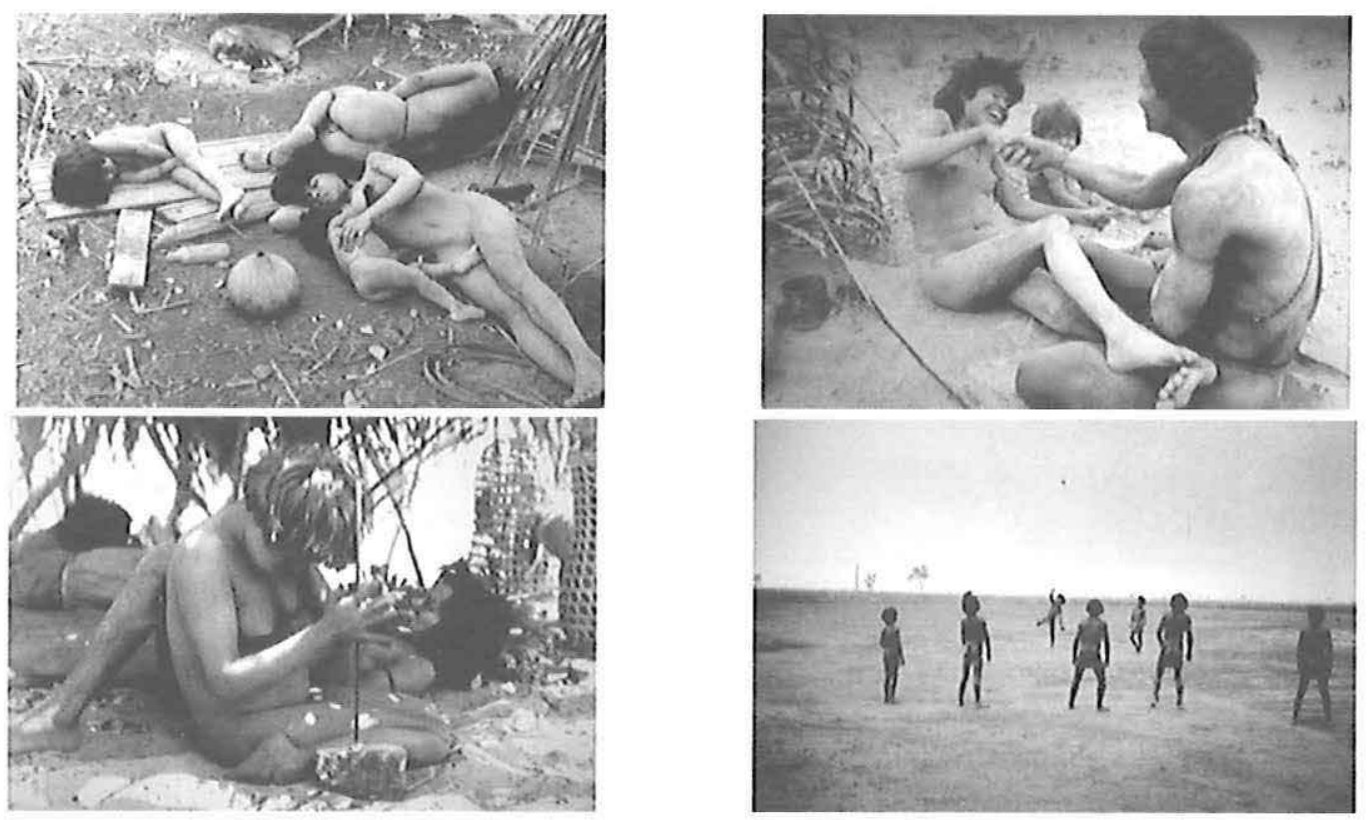

Nambikwara habitus, body techniques, postures, and games

(Lévi-Strauss 1938)

I would therefore say that Lévi-Strauss attempted to find the particular style of Nambikwara culture through his choice of photographing its indigenous representatives close up, always engaged in some specific activity, even if they are statically held into a meditative reverie, or merely asleep on the barren ground by the ashes of a fire (a characteristic of the Nambikwara already well-known at the time of Lévi-Strauss' expedition).

I believe this was Lévi-Strauss' concern when photographing the Nambikwara. I therefore think that the critical stance taken by some scholars, after the publication of Luís de Castro Faria's Um outro olhar (2001), who claimed that Lévi-Strauss purposely attempted to render the Nambikwara more " primitive » than they actually were at the time by removing the signs of colonial intervention 
from his photographs, should be considered in light of his interest in describing Nambikwara body techniques or corporeal style. Indeed, some of Lévi-Strauss' photographs make it quite clear that he was not trying to conceal anything at all.

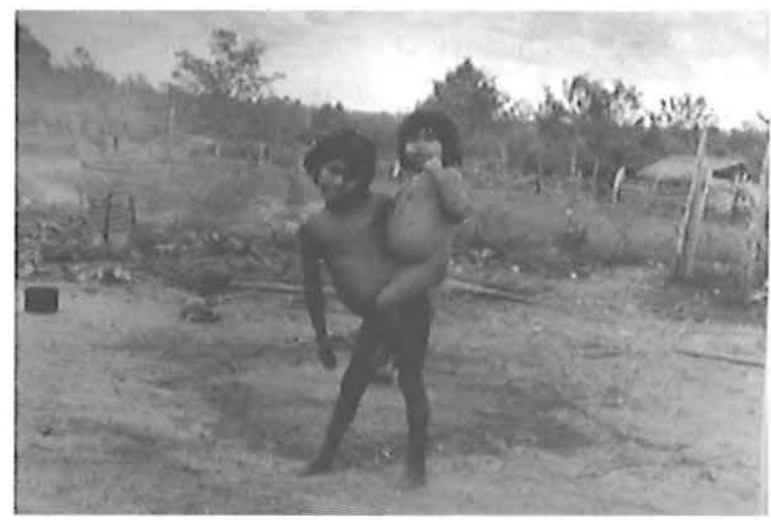

A sibling's participation in child care (Lévi-Strauss 1938)

An example is this lovely photo of a girl carrying a younger sibling, which not only shows the barbed-wired fence behind them but also a shed or corral, a building that immediately reveals colonial presence in the region. Thus, while it is true that many of Lévi-Strauss' photographs do crop out the buildings of the mission and telegraphic line that had been installed in the Nambikwara area, some photos do show elements of these constructions while maintaining their focus on the Nambikwara physical positions and dispositions. Furthermore, to say that Luís de Castro Faria was more aware of the ravages of colonialism than was Lévi-Strauss during their Franco-Brazilian expedition, seems to be quite off the mark. It is well known that Castro Faria - much more than a Brazilian partner to Lévi-Strauss - acted as some kind of surveyor/inspector during the expedition, working for the very organizations and institutions that epitomized colonialism itself. If Luís de Castro Faria's camera focuses more on the colonial context of the telegraphic line built by Rondon, as well as on Lévi-Strauss himself, it is not because he already had a keen postcolonial eye. Some of his photographs of Lévi-Strauss photographing the Nambikwara are probably less meta-commentaries on Lévi-Strauss' aims than expressions of official stance in relation to the expedition: the idea of documenting it. But even Castro Faria left out certain significant aspects of the expedition. Given the prevailing xenophobia of Getúlio Vargas' "Estado Novo » in 1938, one should acknowledge that 
Lévi-Strauss was already taking considerable political risk by simply investigating, in the very presence of functionaries of the Line, the burial grounds of the Nambikwara killed during the contact years. According to Castro Faria (2001, p. 110) himself, some of the vestiges found in these sites pointed to genocide.

In sum, as a counter-claim to the idea that Lévi-Strauss' photographs eschew any relationship to history, I argue that by concentrating on the Nambikwara body, on Nambikwara gestures, postures, and movements, Lévi-Strauss' portraits can tell us about a kind of social continuity inscribed in their bodily habits. As such, Lévi-Strauss' Nambikwara photographs may serve similar purposes as Guido Boggiani's drawings of Caduveo facial paintings and can allow us to investigate the persistence of their bodily expressions (Boggiani 1895).
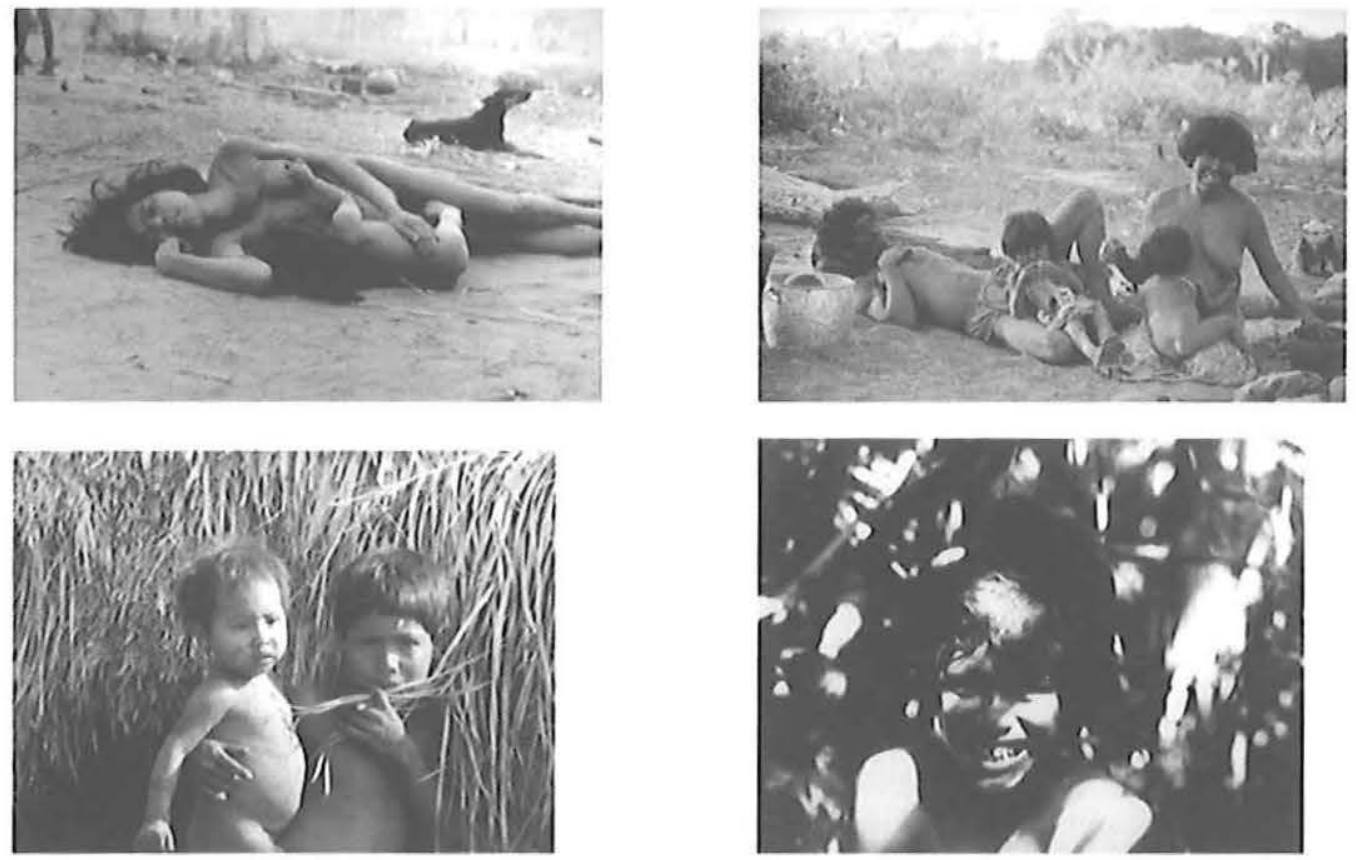

Scene of Nambikwara daily life in 1938 (above left, Lévi-Strauss) and photos of the Wasusu (Nambikwara of the Guaporé) in 1987 (above right and bottom, Fortaleza Flores)

My own photographs of the Nambikwara often reveal similar traces of this embodied continuity, even though they were taken over 50 to almost 70 years 


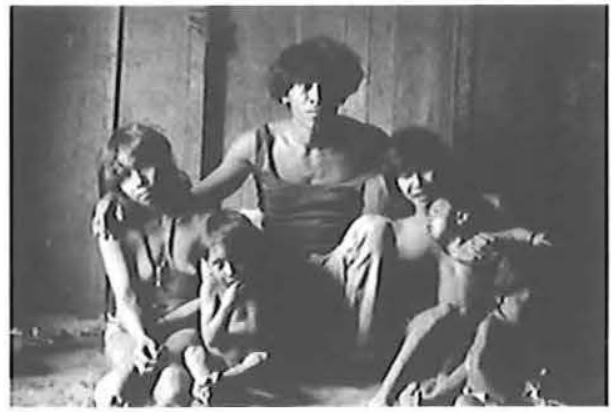

Wasusu Familya (Nambikwara of Guaporé) in 1987
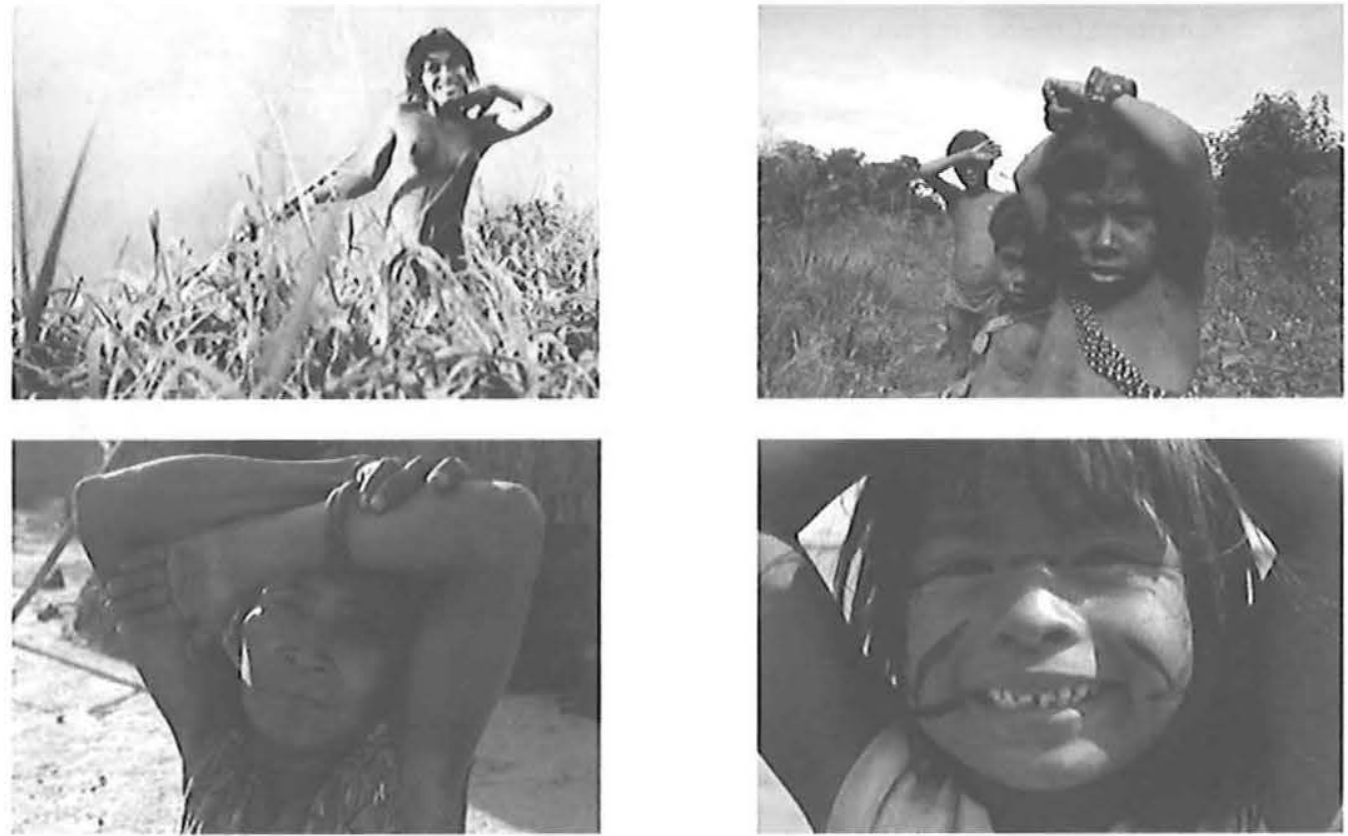

A gesture signifying embarrassment among the Wasusu (above, 1987), the Sararé (bottom left, 2007. Nambikwara, Guaporé Valley), and among the Vakalitesu, 2007 (photos Fortaleza Flores)
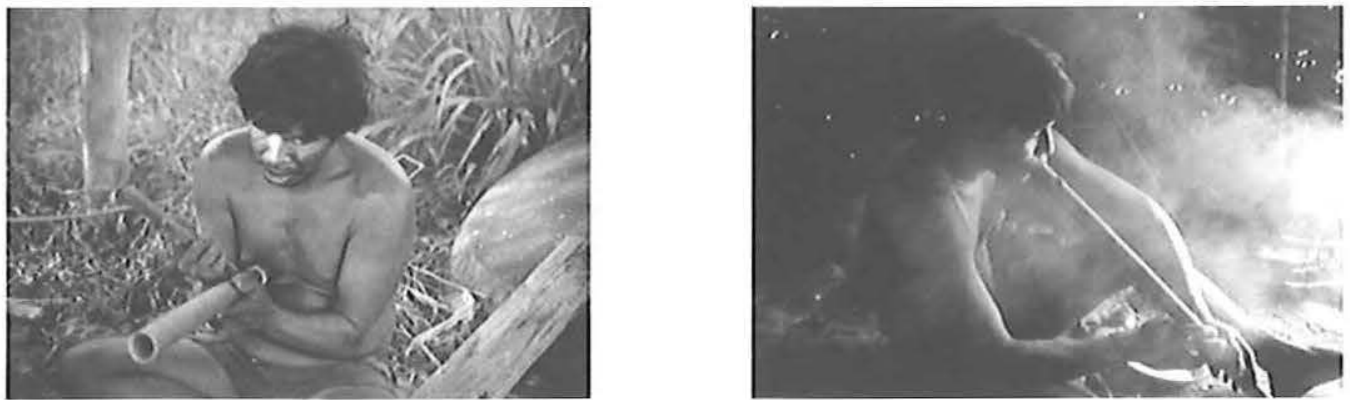

Making flutes among the Wasusu in 1987 and playing them among the Sararé, 2007 (photos Fortaleza Flores) 
after the photographs of Lévi-Strauss. Apart from this, my photographs also reveal that these forms of embodiment extend to other body postures and ways of expressing themselves through the body.

But let us now return to Lévi-Strauss' photographs and what they can tell us about Nambikwara culture. Beyond an anthology of their body techniques and testimony of their persistence through time, what should most raise our interest in them is the message they convey. Consider for instance a photo such as that of the day-dreamer ( La Rêveuse): a young woman from the group who, from her sitting position on the ground, and leaning her head on her arm, seems lost in thoughtful reverie. She seems to be an embodiment of the nostalgia that Lévi-Strauss encountered in the tropics.

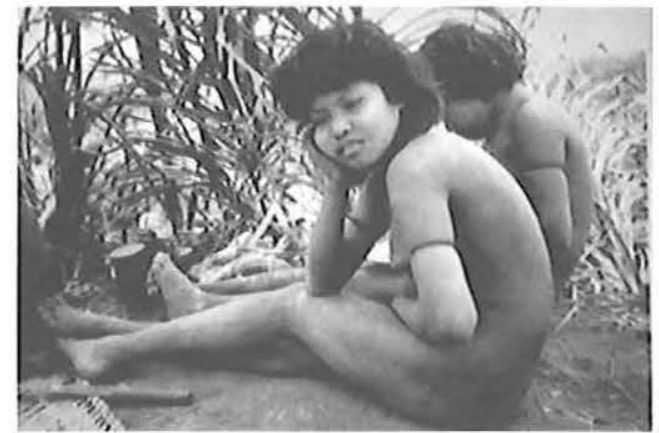

La rêveuse (Lévi-Strauss 1938)
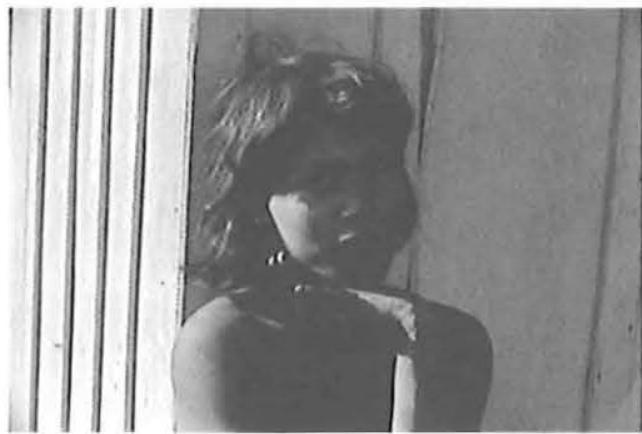

La rêreuse Wasusu, 1987 (photo Fortaleza Flores)

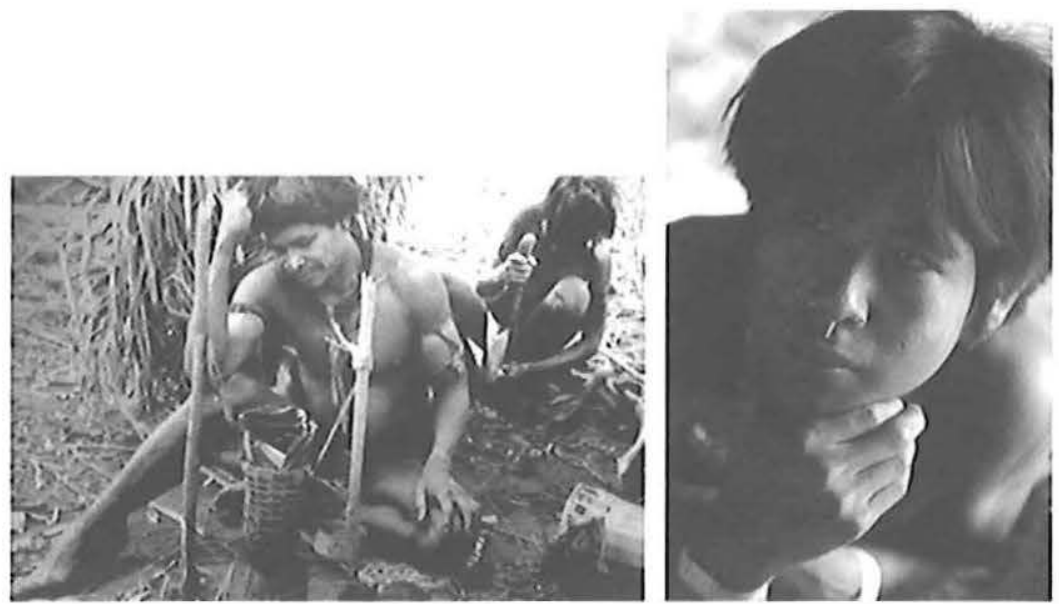

Le penseur (Lévi-Strauss 1938) and Sararé youth after piercing, 2007 (photo Fortaleza Flores) 
I believe Lévi-Strauss' photographs focused on such kinds of bodily attitudes precisely so as to reveal the daily occurrence of what he saw as being a characteristic expression of the Nambikwara melancholy. Actually, to establish this kind of melancholy as a social characteristic, one would need more extensive life histories of individuals to assess the people's inclinations. A proper assessment of this situation, nevertheless, is something Lévi-Strauss did not have the time or the chance to do. But the fact that one can also find this predisposition to daydreaming among many Nambikwara people today, does at least substantiate LéviStrauss' suggestion that Nambikwara bodily postures may reveal such a characteristic as well as other ones.
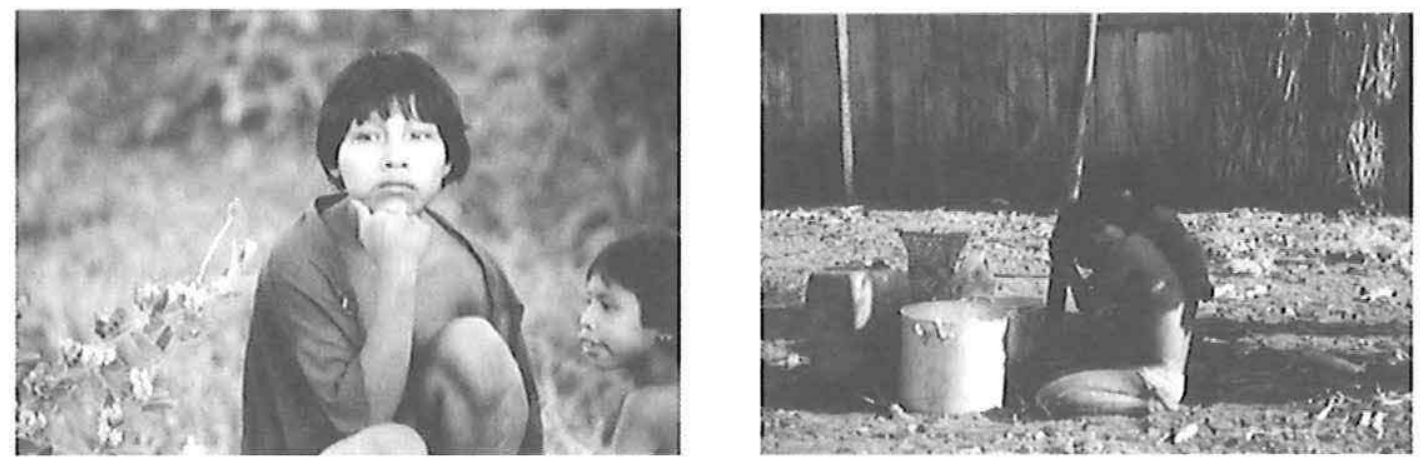

Méditations, Wasusu women day-dreaming, during a fruit gathering foray (left) and at work in the village (right), 1987 (photos Fortaleza Flores)

Lévi-Strauss' photographic accomplishment was to have managed to catch the young Nambikwara women and men in such postures, although, in this case, he definitely benefited from the fact that the Nambikwara, as he has said, did not yet understand photography, and thus did not pay any attention to his taking pictures of them. Indeed, some of the scenes that Lévi-Strauss managed to photograph at the time of his fieldwork among the Nambikwara are quite rare nowadays. It is difficult today to catch someone in a daydream, and even more difficult to surprise people in demonstrative outbursts, like the ones in which Lévi-Straus shows the Nambikwara's embracing, engaged in the practice he defines as «fake love-making " both in hetero- and " homosexual » relations. Such « fake love-making » is diflicult to observe today not only because of the historical presence of missionaries in the area, but also because the Nambikwara today are quite aware of photography, and some groups are quite reserved about its use ${ }^{3}$. 


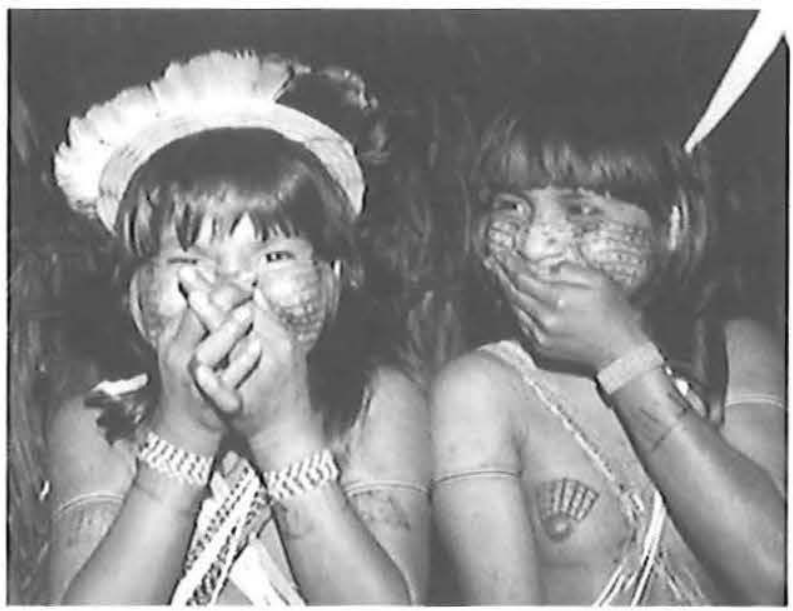

Camera conscious Mamaindê girls, 1992 (photo Fortaleza Flores)

Many Nambikwara groups had no significant pictorial tradition at the time of Claude Lévi-Strauss' fieldwork, and when I arrived in 1986 among the Wasusu, a rather isolated Nambikwara-speaking group, many people still did not know how to look at photographs (they held them upside down and had to make an effort to perceive the images in them before correcting their mistake). Obviously, once they learned the operation, they mocked those among them who had a difficult time looking at pictures, as it is still the case with some older people who never grew accustomed to them. Nowadays, the situation has changed completely, and one of the main expressions of the archival use of photographs is the very group Lévi-Strauss studied in greater depth: the Wakalitesu.

Beginning in 1938, soon after Lévi-Strauss' visit, the mission began to collect photographic records of the Wakalitesu. The Wakalitesu have kept such photographs as a form of preserving a relationship with their past, in a way that is certainly not characteristic of the Nambikwara. In their case, however, this seems to be an attempt at revitalization due to the destruction of many of their cultural practices (and the disruption of other ones) by the Jesuit mission that settled in Utiarity years after Lévi-Strauss' expedition ${ }^{4}$.

One member of the Wakalitesu group in particular, Tito, was a child from a neighboring group who came to live with the Wakalitesu at the time of LéviStrauss' expedition. Although it is difficult to specify his actual age, and the missionary records seem flawed, Tito has been stating for a few years that he recalls the coming of the expedition and of Lévi-Strauss himself. Being an orphan, Tito was taken away from the Nambikwara area by the missionaries a few years after the arrival of Lévi-Strauss' expedition. He was sent by the 
missionaries to live first in Diamantino, and then in other cities in Mato Grosso and later in Rio de Janeiro ${ }^{5}$.

It is clear that Tito's memory of Lévi-Strauss is mixed with other information he gathered during his years in the cities among the Whites (and now, even more so, by the importance given to Lévi-Strauss during my research for the film). Nonetheless, the accuracy of some of his statements is striking. He recalls that the expedition came with over thirty head of cattle; that they stayed several weeks at Utiarity and then traveled to Juruena and into the Campos Novos area to the north. He recalls Lévi-Strauss as a leader of the expedition. He has also created a nickname for Lévi-Strauss, Mássimo Lévi, whose origin is diffïcult to determine, but seems to be tied to the fact that the members of the expedition identified Lévi-Strauss as « Professor Lévi ». Another possibility is that Tito's association of Lévi-Strauss as a leader depends on the usual perception by the Nambikwara of leaders as people of tall stature. Whether or not this was done in retrospect, and after visiting several museums in the cities, as Tito has acknowledged to have done, is very difficult to know, as it is difficult to know whether the recollection he has of photographs is accurate or not. In any case, Tito has recognized people in the categories of " brother ", « mother » and even recognized himself both in the photographs kept by the mission and (albeit only once in one of our visits) in Lévi-Strauss' photographs themselves. What can be said with accuracy is that Tito seems to have a fragmented recollection of that time and that he has attempted to reconstruct his own past. When asked what Lévi-Strauss was interested in, Tito replied that he recalls how he was interested in the plants they cultivated, in their weapons and in their basketry, which seems to be a sound recollection of an ethnographer (Tito has never defined the missionaries in such a way, for example).
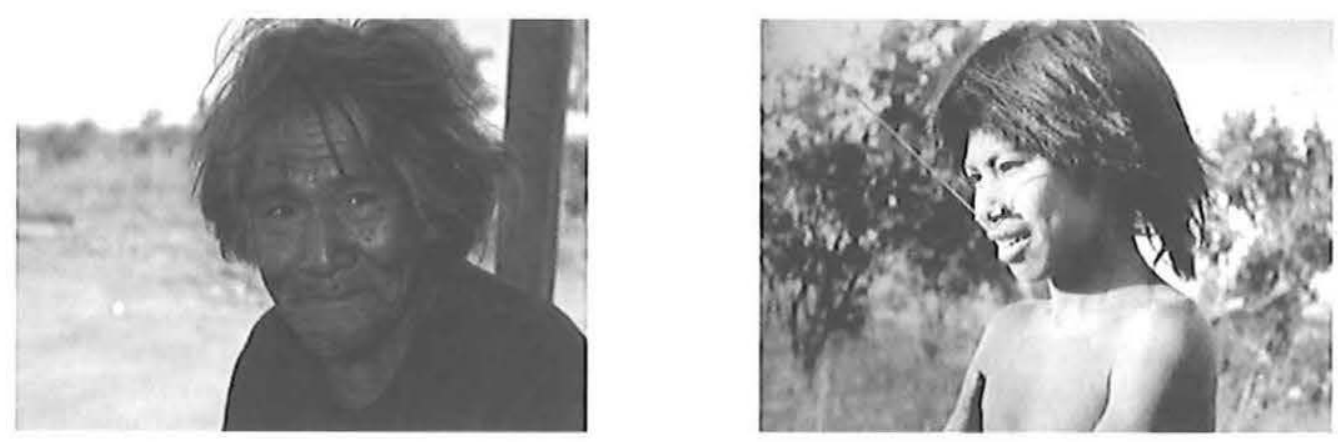

Tito Wakalitesu in 2006 (photo Fortaleza Flores) and on the photo by Lévi-Strauss (1938) he recognized as being of himself 
One of Lévi-Strauss' most eloquent passages in Tristes Tropiques describes how his main informant, Julio Katunkalosu, understood the properties and the significance of writing. Interestingly, however, the word for recording images in Nambikwara, ũh wa li has the same meaning as " writing ». It is no wonder then that the Wakalitesu have learned to keep such photographs as a way of rewriting their past even after the missionaries had left. What seems clear today is that Lévi-Strauss' photos themselves are also on the way to becoming an integral part of Nambikwara culture and will inevitably mediate the Nambikwara's relationship to their own past from now on.

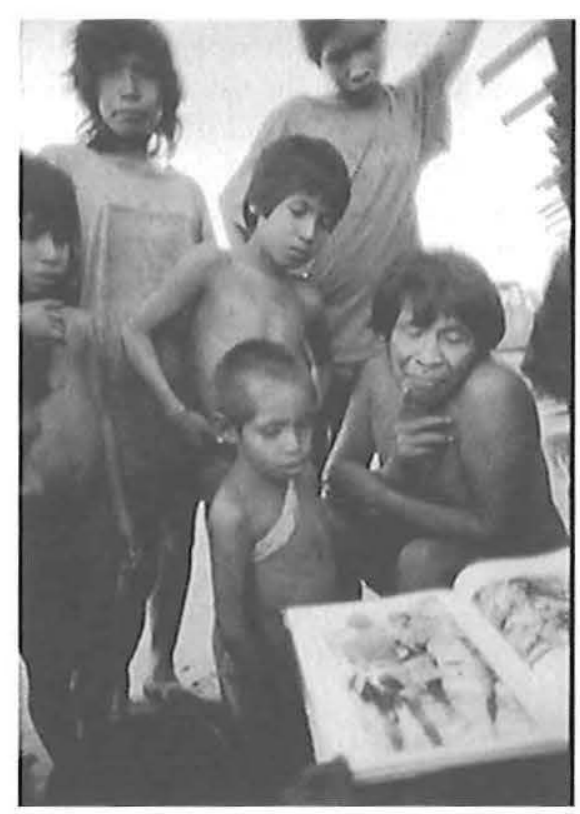

Wasusu looking at Saudades do Brasil, 1994

(photo Fortaleza Flores)

\section{NoTES}

1. " De faşon insidieuse, il [ce remède à leurs contradictions] a contribué à les troubler: Et puisqu'ils ne pouvaient pas en prendre conscience et le vivre, il se sont mis à le rêver " (Lévi-Strauss 1955, p. 169).

2. These images have recently been featured in my film Claude Lévi-Strauss, auprès de l'Amazonie (Fortaleza Flores 2008, 52'), produced for French television.

3. Fake love-making is a translation of the term Timindage Kihandage which Lévi-Strauss renders as an explanation given to him about this attitude by the Northern Nambikwara. The few times I witnessed such outbursts in the field, I was able to record them only on video. On such occasions, I was 
able to capture men engaged in joking relationships with obvious sexual content, and couples engaged in public expressions of their love relationship in playful, non-sexual ways. One of such scenes appears in my film (cited above): Claude Lévi-Strauss, auprès de l'Amazonie (ibid.).

4. In 1935, the Jesuits established themselves near the Telegraphic Post of Major Amarante, close to the headwaters of the Juruena River, to the west of Utiarity, taking advantage of the vacuum left by the protestant mission, whose missionaries had been killed by the Nambikwara a few years previously. The information about the history of the mission is available through the Brazilian NGO, OPAN (Operação Amazônia Nativa) as well as the Wakalitesu's ethnohistory.

5. Tito is listed in the missionary census as being 73 years old, almost the same age as Valdemar ( 70 years old), the Wakalitesu shaman, who states Tito was a young man at the time of his own childhood. Thus, it is more likely Tito is about 85 years old today. It is often the case that missionaries and government agencies in the region have underestimated a child's age, since they do not usually acknowledge the effects of epidemics and consequent malnutrition on the children.

\section{REFERENCES}

\section{Castro Faria Luíz de}

2001 Um outro olhar: Diário da expedição à Serra do Norte, Ouro Sobre Azul, Rio de Janeiro

Mauss Marcel

1934 "Les techniques du corps », communication présentée à la Société de Psychologie, le 17 mai 1934 [publiée in Journal de Psychologie, XXXII (3-4), 15 mars15 avril 1936].

MEAD Margaret and Frances Cooke MACGregor

1951 Growth and culture: a photographic study' of Balinese childhood, with photographs by Gregory Bateson, G. P. Putnam's Sons, New York.

\section{BogGIANI Guido}

1895 Caduvei (Mbayá o Guaicurú). Viaggio d'un artista nell' America Meridionale, Ermanno Loescher, Rome [Os Caduveo, translated and annotated, Livraria Martins Editôra, Biblioteca histórica brasileira 14, São Paulo, 1945].

\section{Lévi-Strauss Claude}

1955 Tristes Tropiques, Union générale d’éditions, coll. « 10/18 », Paris.

1994 Saudades do Brasil, Plon, Paris.

\section{LowIE Robert}

1920 Primitive Society, Boni and Liveright, New York. 